\title{
ARCADIO TORRES MARTÍN Y SUS NEGOCIOS AL SERVICIO DEL TRÁFICO DE OBRAS DE ARTE DESDE ESPAÑA A ESTADOS UNIDOS*
}

\author{
María José Martínez Ruiz ${ }^{1}$ \\ Universidad de Valladolid
}

\begin{abstract}
Arcadio Torres Martín fue un destacado anticuario; protagonista del tráfico de obras de arte desde España a EE. UU. en los años anteriores a la Guerra Civil, durante la posguerra y la dictadura de Franco. Estudioso del arte, miembro de la Institución Cultural Tello Téllez de Meneses (Palencia), tomó parte en la venta de obras de arte procedentes de San Andrés de Arroyo (Palencia), las tablas de Juan de Flandes procedentes de San Lázaro de Palencia y el ábside de San Martín de Fuentidueña (Segovia), entre otras. Contó con la confianza de ciertos obispos y gestó un lucrativo negocio de antigüedades en paralelo a su destacada posición social como amante del arte. Acompañó a personajes destacados, como al hispanista W. S. Cook o al embajador estadounidense en España, en sus visitas a monumentos españoles y ofertó obras al Metropolitan Museum of Art de Nueva York.
\end{abstract}

Palabras clave: antigüedades; venta; exportación; Juan de Flandes; San Lázaro; facistol; Fuentidueña; Santa Eufemia de Cozuelos; dictadura.

\section{TORRES MARTÍN AND HIS BUSINESSES AT THE SERVICE OF ART TRADE FROM SPAIN TO THE UNITED STATES OF AMERICA}

Arcadio Torres Martín was an outstanding antique dealer; main character of art works trade from Spain to the USA during previous years of Spanish Civil War, during the postwar period and the Franco dictatorship. Scholar of art, member of the Tello Tellez de Meneses' Cultural Institution (Palencia), he took part in the sale of art works from San Andrés de Arroyo (Palencia), Juan de Flandes paintings from San Lázaro de Palencia, the apse of San Martín de Fuentidueña (Segovia), among others. He counted on the confidence of certain bishops and he built a lucrative antiques business in parallel to his prominent social position as an art connoisseur. He accompanied relevant personalities such as the hispanist W. S. Cook or the American ambassador to Spain on their visits to Spanish monuments and offered art works to the Metropolitan Museum of Art in New York.

Key words: antiques; trade; export; Juan de Flandes; San Lázaro; lectern; Fuentidueña; Santa Eufemia de Cozuelos; Franco's dictatorship; cultural heritage.

Cómo citar este artículo / Citation: Martínez Ruiz, María José (2021) “Arcadio Torres Martín y sus negocios al servicio del tráfico de obras de arte desde España a Estados Unidos”. En: Archivo Español de Arte, vol. 94, núm. 374, Madrid, pp. 143-162. https://doi.org/10.3989/aearte.2021.09

\footnotetext{
* Trabajo realizado dentro del Proyecto de Investigación: HAR2017-84208-P. La autora es miembro del GIR de la Universidad de Valladolid: Arte, Poder y Sociedad en la Edad Moderna. Agradecemos las facilidades ofrecidas por el Archivo del Metropolitan Museum of Art, Nueva York para el desarrollo de esta investigación, y de manera singular a James Moske.

${ }^{1}$ mjmruiz@fyl.uva.es / ORCID iD: https://orcid.org/0000-0002-3696-7147
} 


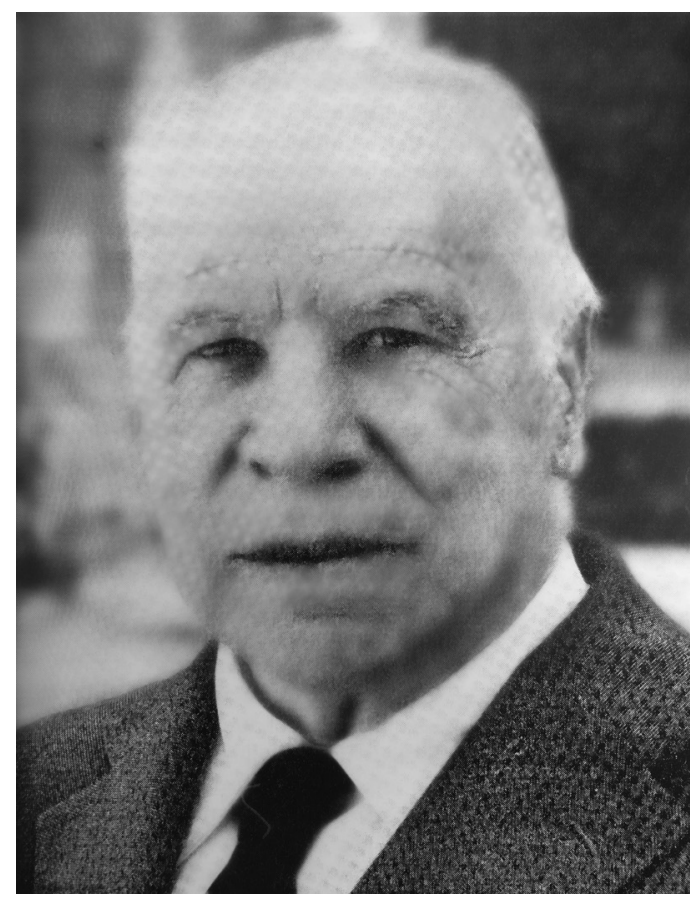

Fig. 1. Arcadio Torres Martín. Fotografía publicada en su necrológica. Ángel Sancho Campo (1999). Imagen original de baja resolución, retocada para el presente estudio por Rasgos Imago, Valladolid.

Recomponer las piezas diseminadas del puzle del pasado, a veces nos regala singulares episodios dignos de vertebrar un relato propio de la ficción. El periplo seguido por un funcionario de Correos, de la sección de giros postales, Arcadio Torres Martín (†1998), [fig. 1] hasta convertirse en un destacado anticuario con proyección internacional, en la España de los años inmediatos a la Guerra Civil y durante la posguerra y dictadura, merece tal relato.

Esto es así por diversas razones, la primera de ellas porque encarna magníficamente buena parte de las contradicciones propias de la historia cultural española del siglo XX, donde ciertas personas con gran reconocimiento social, como estudiosos del arte, desarrollaron paralelamente un lucrativo negocio comercial liquidando y procurando la exportación de obras de $\operatorname{arte}^{2}$. Así fue en el caso de Torres, como miembro destacado de la Institución Tello Téllez de Meneses (Palencia), de la cual fue uno de sus fundadores.

La venta y desaparición de obras procedentes de San Andrés de Arroyo (Palencia), Santa Clara de Palencia, San Pedro de las Dueñas (Sahagún), las tablas de Juan de Flandes procedentes de San Lázaro (Palencia), el ábside de San Martín de Fuentidueña (Segovia) son apenas algunos de los despojos tras los cuales se descubre la actividad de Torres. Beneficiado por la confianza de ciertos obispos en tales labores, su presencia social fue creciendo merced al lucrativo negocio de las antigüedades. De ahí que acompañara al hispanista W. S. Cook en sus visitas a monumentos castellanos, al embajador estadounidense en España, o escribiera en 1959 al entonces director del Metropolitan Museum of Art de Nueva York, James J. Rorimer (1905-1966), a fin de ofrecerle distintos ejemplares de la riqueza artística española, todo ello a pesar de desconocer el idioma de Shakespeare. Episodio aquel último, como veremos, no exento de una cierta dosis de absurdo, a la par que amarga realidad, cual si fuera extraído de una película de Luis García Berlanga. Y es que, como señalábamos al principio, esta pequeña historia entraña matices propios del relato ficticio.

\section{Su faceta más conocida: destacado miembro de la élite social y cultural palentina}

Arcadio Torres Martín fue conocido en su tiempo como gran amante del arte y la historia palentina. Editó diversos estudios relativos a estos temas ${ }^{3}$. Además, colaboró con Ramón Revilla Vielva en la redacción y revisión del Catálogo Monumental de la Provincia de Palencia ${ }^{4}$, así

\footnotetext{
2 Véanse, por ejemplo, los casos de Lluis Plandiura: Wunderwald/Berenguer, 2001: 121-130, Josep Pijoan: Socias/ Gzozgkou 2012: 87-96, Arthur Byne: Merino/Martínez: 2012, o el marqués de la Vega-Inclán: Menéndez: 2006. Kagan: 2013, pp. 193-203.

3 Torres, 1963: 227-228. Torres, 1953: 313. Torres, 1953: 314-316. Torres, 1951: 149-150.

${ }^{4}$ Revilla Vielva, 1930. Revilla Vielva/Navarro García, 1948.
} 
como en otra serie de estudios sobre el arte de la provincia 5 . Torres, además, llegó a desempeñar el cargo de Jefe local de Protección Civil para la defensa del Patrimonio Artístico de Palencia, así como el de vocal diocesano de Arte $\mathrm{Sacro}^{6}$. De igual modo, a fines de los años cincuenta tomó parte en las labores de promoción del legado cultural castellano en Bélgica con estudios sobre Pedro Berruguete, acerca de los tapices de la catedral de Palencia que viajaron a Gante, y sobre Juan de Flandes - en este caso, con motivo de la restauración de las tablas pintadas correspondientes al retablo mayor de la expresada catedral ${ }^{7}$.

Como académico de la Institución Cultural Tello Téllez de Meneses pronunció en 1971 el discurso de inicio del curso académico bajo el título: "El Arte en Palencia a través de los tiempos". Procuró, de igual modo, el ingreso como académicos en la expresada institución de su hija, María Luisa Torres Jubete y de su yerno, el ginecólogo: Colomán Casasnovas. Revelador todo ello de la estrecha vinculación con la vida académica de la corporación hasta que en 1999 Ángel Sancho Campo firmó su necrológica en la memoria anual de la misma9 .

\section{De aquello menos conocido: sus negocios como anticuario}

Torres llegó a la provincia de Palencia como funcionario de Correos; fue en 1919 cuando aprobó las oposiciones nacionales ${ }^{10}$. Ahora bien, su dedicación principal fue otra: el negocio de antigüedades. Según la prensa de la época, se desligó del trabajo en la oficina de correos "para dedicarse a otros quehaceres más en consonancia con sus aptitudes y hábitos"11. Esos quehaceres no eran otros que la compra-venta de obras de arte. Así por ejemplo, en 1927 envió una carta al obispado de Orense interesándose por el conjunto de esmaltes de Limoges de la catedral, si bien el cabildo no adoptó solución alguna al respecto ${ }^{12}$.

Su negocio procuraba dirigir la mirada al mercado internacional, y singularmente al estadounidense, pues conocía bien la intensa demanda de los coleccionistas norteamericanos, así como las cifras ofertadas en dicho circuito por las antigüedades procedentes de España, lo cual podía reportarle mayores beneficios. Domiciliado en la calle Valentín Calderón, en el centro de Palencia, trabajó en muchas ocasiones en colaboración con su hermano, Víctor Torres Martín, quien residía en esos años en la calle Muro de Valladolid. Ambos procuraron proveer de obras de arte, de muy diverso signo: techos, fragmentos arquitectónicos, sillerías, esculturas, pinturas, puertas, tejidos, etc. a otros anticuarios y agentes internacionales, asentados en Madrid, quienes abastecían el ávido mercado de antigüedades estadounidense, como era el caso de Arthur Byne o Raimundo Ruiz.

Así pudo apreciarse en la operación llevada a cabo en el monasterio de San Bernardino en Cuenca de Campos (Valladolid), cuyo artesonado fue vendido a Arcadio Torres en $1930^{13}$, probablemente el mismo techo que Arthur Byne vendió el 20 de junio de 1930 a su cliente W. R.

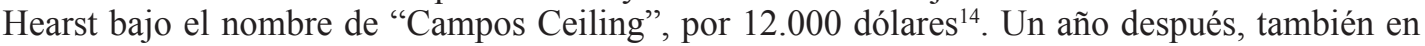

\footnotetext{
${ }^{5}$ Revilla Vielva/Torres Martín, 1977. Revilla Vielva/Torres Martín, 1954: 45-60. Aguado/Torres Martín, 1976. Revilla Vielva/Torres Martín, 1951: 345-360.

${ }^{6}$ Labor que desempeñó hasta 1987, momento en el cual el obispo Nicolás Castellanos le escribió para "agradecerle su colaboración en el periodo anterior y comunicarle, a la vez, que su puesto en la Comisión será cubierto para esta nueva etapa por D. Santiago Pastor Suazo". Carta del obispo de Palencia, Nicolás Castellanos, a Arcadio Torres, 26 de enero de 1987. Archivo Diocesano de Palencia. (ADPA) Agradecemos al Director del expresado archivo, Dionisio Antolín, la información y el documento facilitado.

7 Torres, 1958: 144-145.

8 Torres, 1971: 9-19.

9 Sancho, 1999: 608-609.

10 "La última convocatoria de Correos. Opositores aprobados", La Correspondencia de España, 27/08/1919.

11 "Los buenos patriotas y la suscripción nacional", El día de Palencia, 19/11/1937: 1.

12 Gallego, 1989: 61-69. Requejo, 2004: 269.

13 Pérez, 2003: 111.

${ }^{14}$ Parte de dicho techo fue empleado en una de las estancias de la casa grande de la finca californiana de W. R. Hearst en San Simeón (California), hoy conocida como Hearst Castle. Merino/Martínez, 2012: 656. Martínez, 2018: 279. Telegrama de W. R. Hearst a Julia Morgan, 14 de abril de 1930, CalPoly. Kennedy Library Archive, California Polytechnic State University. Julia Morgan Papers. 010-5-e-55-10-10.
} 
Tierra de Campos, en este caso en el monasterio benedictino de San Pedro de las Dueñas (León), los hermanos Torres adquirieron, desmontaron y extrajeron diversas obras: el techo del coro bajo de la iglesia, un arco románico de piedra, una escultura de un Cristo, así como diversos cuadros y lienzos, que fueron cargados en camiones y trasladados por la noche al palacio episcopal de León. Así fue comunicado al gobernador civil de León, Matías Peñalba, en abril de $1931^{15}$. El arco románico de piedra permaneció hasta los años cuarenta en la sede episcopal leonesa hasta que en 1943 fue ofertado por Víctor Torres en venta al Estado por 70.000 pesetas, si bien en el curso de las negociaciones hubo de rebajar el precio inicial y finalmente la transacción fue cerrada en 1945 por 40.000 pesetas, razón por la cual hoy se conserva en el Museo Arqueológico Nacional ${ }^{16}$. De igual modo, según refiere Cortés Álvarez de Miranda, el cristo crucificado procedente del convento de Basilios de Bárcena de Campos (Palencia), fue vendido en 1933 a Arcadio Torres ${ }^{17}$.

Gracias a tales negocios el anticuario alcanzó una acomodada posición que le permitió participar activamente de la vida social y cultural de la provincia. Así se aprecia en las crónicas de prensa, pues era habitual su presencia en los eventos de eco nacional, por ejemplo en la visita de Federico García Sanchíz (1886-1964), tal y como recogieron las páginas del diario $A B C$ en $1935^{18}$.

Durante la Guerra Civil se reincorporó a su puesto en la oficina de Correos de Palencia, en la sección de giros postales, lo cual fue difundido por la prensa palentina como un ejemplo de patriotismo: "no se ha contentado este digno funcionario con su reintegración a un trabajo que le absorbe muchas horas del día en penosa labor de ventanilla, sino que, deseando prestar una mayor y más eficaz aportación a nuestra gloriosa cruzada nacional, ha dado y viene dándola el fruto íntegro de su esfuerzo personal" 19 .

Su contribución al bando nacional, no solo se sustanció en la donación de su sueldo como funcionario de correos, sino en una participación activa en toda suerte de cuestaciones abiertas durante los años de la contienda y la posguerra ${ }^{20}$. Este compromiso con los nacionales, así como su cercanía al obispado de Palencia, hubo de resultar muy provechoso para sus negocios, pues durante la posguerra estos se intensificaron, contando con unas condiciones muy favorables desde las instituciones y principalmente desde el entorno eclesiástico.

\section{Anticuario de referencia en la diócesis de Palencia durante la década de los años cuarenta y cincuenta}

Durante la década de los años cuarenta documentamos a Arcadio Torres haciéndose con obras de arte procedentes de diversos puntos de la diócesis palentina. Es preciso señalar que en buena parte de tales transacciones aparece como tasador Ramón Revilla Vielva (1882-1978), quien desempeñó, entre otros cargos, el de comisario provincial de excavaciones arqueológicas ${ }^{21}$, secretario de la comisión provincial de monumentos y director de la Biblioteca y Museo Arqueológico de Palencia. Por tanto, en los años en los que se hallaba recorriendo la provincia, a fin de elaborar el Catálogo Monumental, Torres acompañó a Revilla Vielva y, durante el curso de tales visitas, algunas obras fueron seleccionadas para ser vendidas, así hemos podido constatar en algunos casos. El anticuario contó, por tanto, con unas condiciones ventajosas para cerrar las transacciones, Revilla Vielva tasaba las piezas que Torres adquiría y el respaldo del obispado de Palencia resultó fundamental para tales operaciones.

Su presencia en los conventos de la diócesis palentina fue habitual durante la Posguerra; las necesidades de las comunidades hallaron una vía de salida en las ofertas que Torres realizaba por

\footnotetext{
15 Martínez, 2008: t. I, p. 151-156.

16 Franco, 2013: 170-172.

17 Cortés, 1999: 491-492.

18 "Un nuevo triunfo de García Sanchíz en Palencia", $A B C, 17 / 11 / 1935$, p. 34.

19 "Los buenos patriotas y la suscripción nacional", El día de Palencia, 19/11/1937.

20 "Para el monumento al llorado general Mola", El día de Palencia, 6/04/1938.

21 Boletín Oficial de la Provincia de Palencia, Año LVI, 71, 13/06/1941, p. 300.
} 


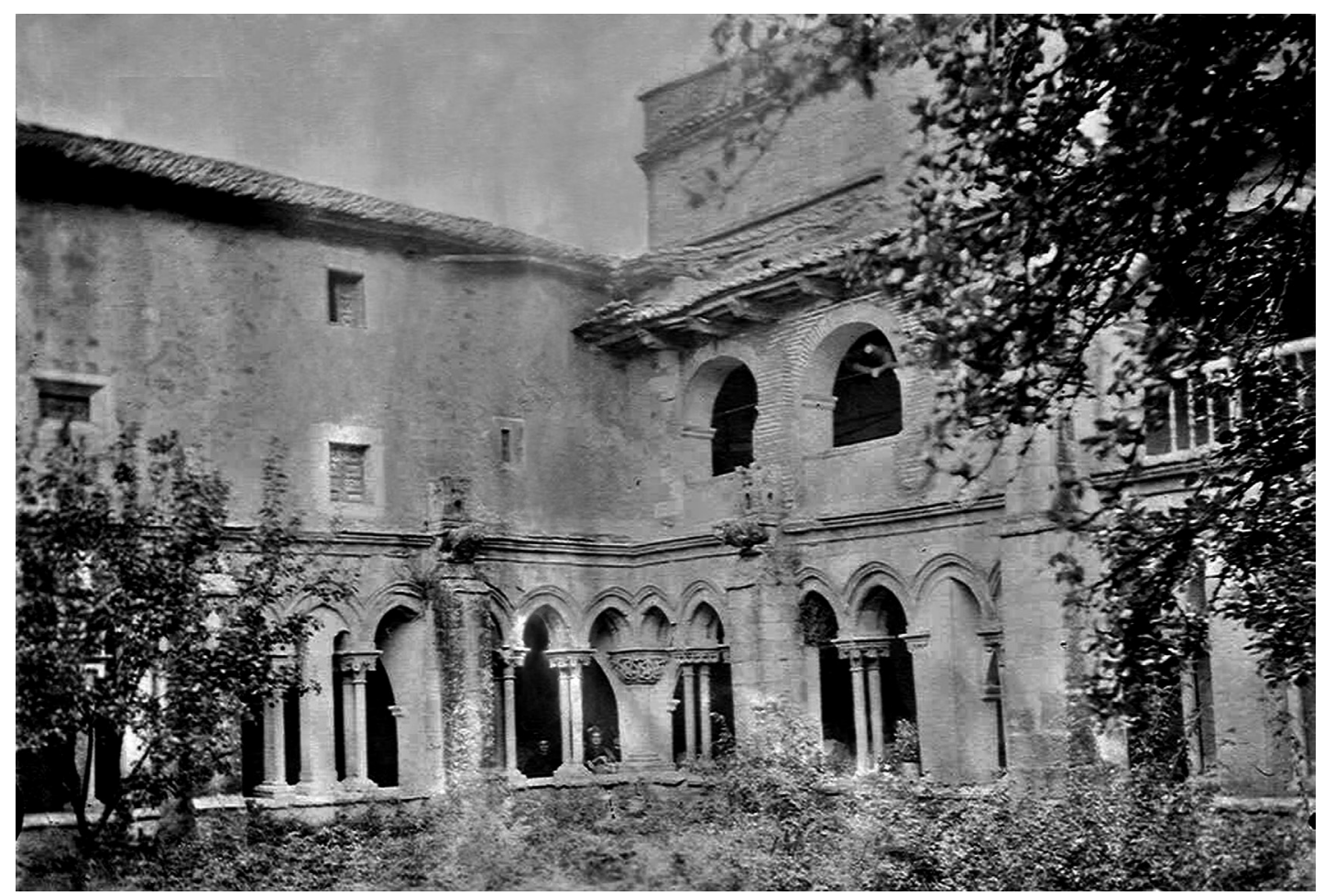

Fig. 2. Claustro de San Andrés de Arroyo (Palencia) antes de la restauración acometida por Anselmo Arenillas. Imagen publicada por Enrique Almaraz (1900).

bienes artísticos custodiados en sus clausuras. Así, en 1940 el obispo autorizó al convento de RR. Carmelitas de Palencia a vender a Torres unos objetos "inservibles", entre los que se contaban: "un reloj de pared en quinientas pesetas, dos cenefas de frontales de púlpito por doscientas pesetas cada una y un cuero de frontal en cien pesetas"22. A las Clarisas, también de la capital: "dos cornucopias y mesitas"23. Mientras que a las Carmelitas les permitió venderle: "una arqueta deteriorada"24. Un año después mostró su interés por "dos sillares viejos" de las Clarisas de Carrión de los Condes (Palencia) $)^{25}$. En el año 1942 el obispo dio su visto bueno a la venta en el convento de Carmelitas de la capital de "algunos medallones de plata, estampas en pergamino y adornos de alfombras en ochocientas veinte pesetas"26.

En la parroquia de Amusco (Palencia) adquirió "una imagen del Salvador, cuatro brazos de candelero, una alfombra y fragmentos de tabla pintada" por 3.900 pesetas más otra alfombra nueva ${ }^{27}$. En 1950 las Madres Dominicas de la capital fueron autorizadas para vender a Torres "dos imágenes retiradas del culto" por 5.000 pesetas $^{28}$, y a la parroquia de Villamuriel de Cerrato (Palencia) $)^{29 ،}$ varios objetos retirados y sin uso a cambio de 2.000 pesetas y un armario nuevo para el servicio en la parroquia"30.

${ }^{22}$ ADPA.Libro de Decretos, 53, núm.121.

${ }^{23}$ ADPA. Libro de Decretos, 53, núm.412.

${ }^{24}$ ADPA. Libro de Decretos, 53, núm. 436.

${ }^{25}$ ADPA. Libro de Decretos, 55, núm. 462.

${ }^{26}$ ADPA. Libro de Decretos, 55, núm. 615.

27 ADPA. Libro de Decretos, 55, núm. 700 y 666.

${ }^{28}$ ADPA. Libro de Decretos, 58, núm. 1429.

${ }^{29}$ García, 1952. Piqueras/Lorenzo, 1966.

${ }^{30}$ ADPA. Libro de Decretos, 58, núm.1563. 
Aquel mismo año, Revilla Vielva, al igual que en las transacciones anteriores, informó favorablemente al obispado de Palencia sobre la enajenación de ciertos elementos procedentes del claustro del monasterio de San Andrés de Arroyo (Palencia) a Arcadio Torres por 50.000 pesetas: "trece castillos y leones del antiguo claustro que no habían sido utilizados en las restauraciones del mismo" 31 . Dicha restauración estaba siendo acometida por Anselmo Arenillas, quien intervino en el monasterio entre 1941 y $1965^{32}$. Sobre los motivos de castillos y leones, objeto de la transacción, hemos de recurrir a la descripción de Navarro García:

A lo largo de las primeras [galerías norte y sur] hay cuatro contrafuertes que las sustentan. En la fila de las segundas hay cinco. Estos contrafuertes están coronados por gárgolas originalísimas que sirven de pináculos de afirmación compuestos de dos elementos del blasón real de Castilla y León: un león tendido de abiertas fauces y sobre sus lomos un castillo de cinco torres $[\ldots]^{33}$.

Es decir, aquellos motivos se encontraban coronando los contrafuertes del claustro. Así se advierte en las imágenes del monasterio editadas en 1900 por Enrique Almaraz ${ }^{34}$ [fig. 2]. No obstante, aquella restauración siguió unas pautas depurativas en estilo, muy comunes en la práctica de la restauración monumental en España en aquellos años ${ }^{35}$, y prescindió de tales esculturas. Naturalmente, el desmonte permitió aprovechar todas aquellas piedras labradas que pudieran cumplir "algún beneficio" para la comunidad, algo de lo que nuestro protagonista dio cuenta.

\section{Venta y exportación de las tablas de Juan de Flandes procedentes de San Lázaro de Palencia}

Una de las operaciones de Arcadio Torres con mayor proyección nacional e internacional fue la adquisición y venta de las tablas de Juan de Flandes: Resurrección de Lázaro, Oración del Huerto, Ascensión, Anunciación, Natividad, Epifanía y Bautismo de Cristo (1514-1519) ${ }^{36}$, procedentes del antiguo retablo mayor de Sancho de Castilla en la parroquial de San Lázaro de Palencia. Según Estrada, en la década de los años sesenta del siglo XVIII fue sustituido aquel antiguo retablo por uno nuevo, si bien se utilizaron en este seis tablas que formaron parte del original ${ }^{37}$. En 1898 se refiere: "El retablo o altar mayor que desde su construcción estaba aislado y elegante, recientemente ha sido retirado y adosado a la pared [...] son de notar algún tanto en su principal Retablo, las pinturas de la Escuela Flamenca que contiene" ${ }^{38}$. A tal emplazamiento han de corresponder las fotografías de las pinturas tomadas por el estudio Moreno [figs. 3 y 4], antes de su venta y traslado a la casa de Arcadio Torres en Palencia, donde entre 1950 y 1951 fueron vistas por Egbert Haverkamp-Begemann ${ }^{39}$ [fig. 5]. En esta operación, además del buen entendimiento del anticuario con el obispado palentino, hubo de resultar provechosa su relación con el propio templo. En este tuvo lugar la boda de su hermano, Víctor Torres Martín, con Josefina Fernández-Lomana Pereletégui, ceremonia oficiada por el tío de la novia, el P. Jesuita Román F. Lomana ${ }^{40}$.

\footnotetext{
31 ADPA. Libro de Decretos, 59, núm. 3.

32 Gutiérrez,1993: 56-66. Martínez, 2010: 119-154. Pardo, 2019: 1457-1462.

33 Navarro, 1939: 205.

34 Almaraz, 1900: 210-229.

35 Martínez, 2010: 119-154. Pardo, 2019: 1457-1462.

36 Brans, 1953: 29-32. Bermejo, 1962. Silva, 2013:25-43. Vandevivere/Bermejo, 1986.

37 Estrada, 2007: 317-320.

38 Álvarez, 1898: 177, cf.: Estrada, 2007:320.

39 https:/www.nga.gov/collection/art-object-page.46121.html\#provenance[16/07/2020].

40 "Ecos de Sociedad", El día de Palencia, 12/10/1928, p. 4.
} 


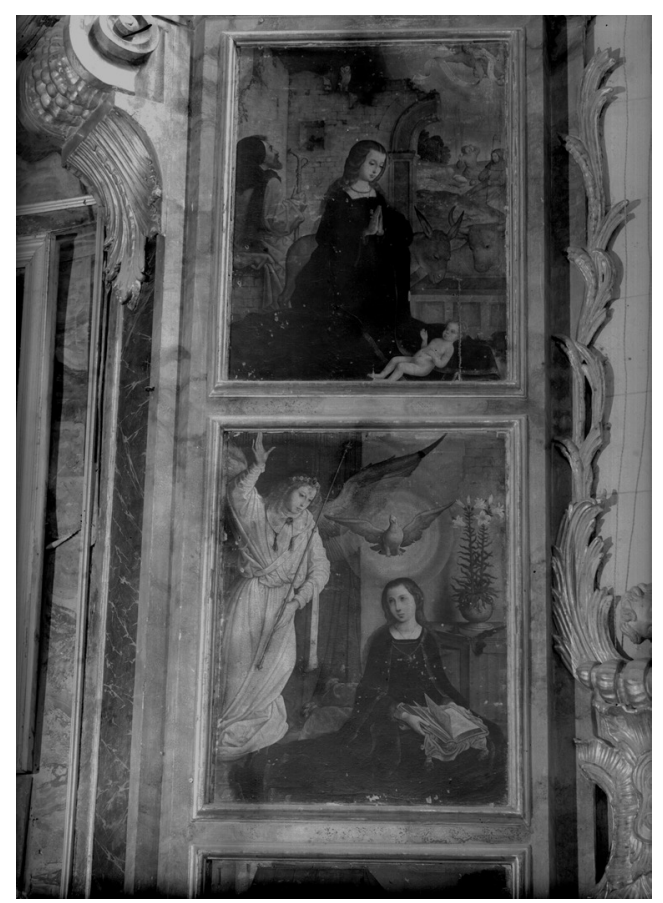

Fig. 3. Tablas de Juan de Flandes en San Lázaro de Palencia antes de su venta: Natividad y Anunciación (Actualmente en National Gallery of Art, Washington). Archivo Moreno. Fototeca IPCE, Madrid.

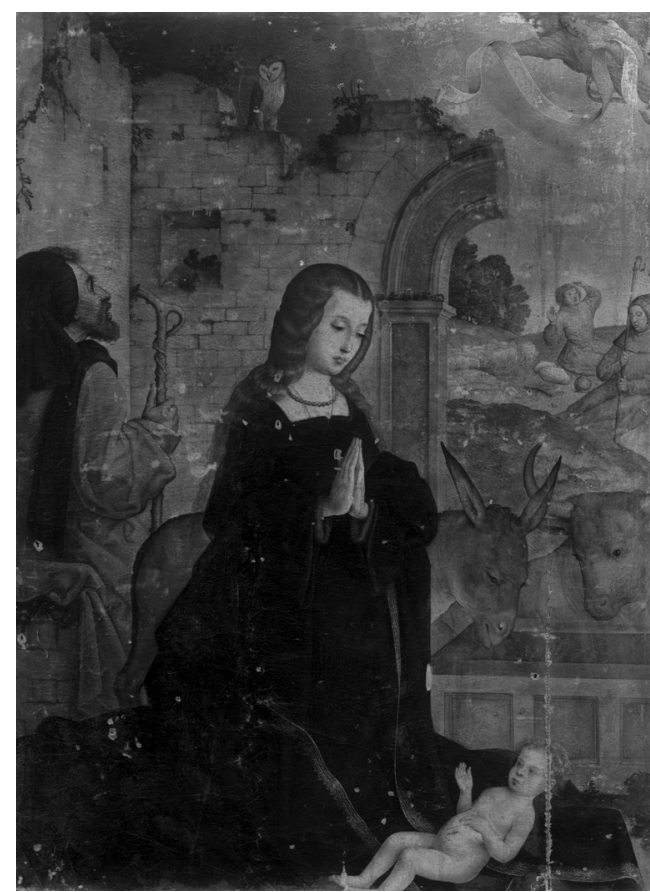

Fig. 5. Natividad, tabla de Juan de Flandes antes de su restauración. Archivo Moreno. Fototeca IPCE, Madrid.

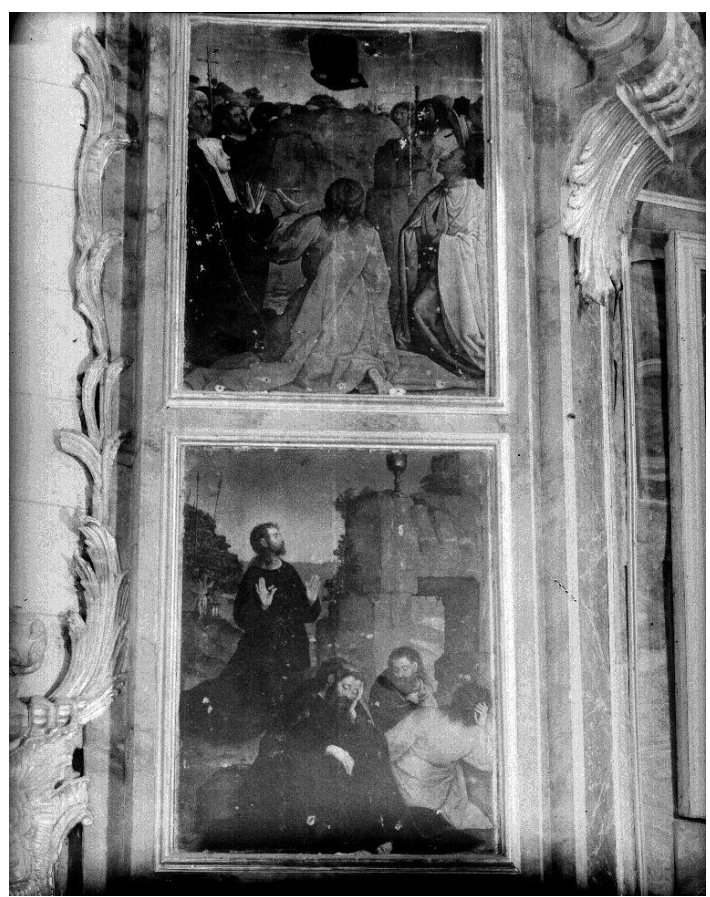

Fig. 4. Tablas de Juan de Flandes, tras su venta y antes de su exportación a EE. UU: Ascensión y Oración en el huerto (Actualmente en el Museo del Prado). Archivo Moreno. Fototeca IPCE, Madrid.

Torres entró en negociaciones para la venta y exportación de las pinturas con Frederick Mont (1894-1994), anticuario procedente de Austria y asentado en Nueva York, quien en representación de la firma Newhouse Galleries, procuró la adquisición del conjunto, lo cual aparece referido en su correspondencia con Chandler R. Post y con Wilhelm Valentiner ${ }^{41}$. Mont finalmente logró hacerse con dos de ellas que puso en manos de su cliente Samuel H. Kress (1863-1955), uno de los mayores coleccionistas de pintura de la época y benefactor de la National Gallery of Art de Washington.

La operación fue compleja y la exportación de las dos tablas del conjunto que actualmente se encuentran en la National Gallery of Art de Washington pudo haberse evitado. En un primer momento la Junta de Exportaciones denegó el permiso de exportación dada la valía de las pinturas, por ello, desde el Ministerio de Educación se aprobó destinar quinientas mil pesetas para su adquisición, al tiempo que se requirió al patronato

${ }^{41} \mathrm{https}: / / w w w . n g a . g o v / c o l l e c t i o n / a r t-o b j e c t-p a g e .46121$. html\#provenance [16/07/2020].Hand/Wolff, 1986: 124-125. 
del Museo del Prado que aunara esfuerzos para ello, pues ese habría de ser el destino de las mismas. Todo ello se contemplaba como una excelente inversión en la medida que no se contaba con presencia de la obra de Juan de Flandes en la pinacoteca nacional. Por esta razón, el Prado aprobó dedicar hasta doscientas mil pesetas para la compra de las pinturas.

Ahora bien, una vez acordada tal medida, gracias a la cual la exportación del conjunto quedaba frustrada y era más que previsible la permanencia en España del conjunto, todo dio un giro con la acción directa de Frederick Mont, quien defendió los intereses de su cliente, el magnate Samuel H. Kress, la mediación de Arcadio Torres y la colaboración del director del Museo del Prado, Fernando Álvarez de Sotomayor y Zaragoza (1875-1960). Desde Nueva York se lanzó una oferta que en España fue contemplada como una excelente transacción. El agente de antigüedades ofrecía ingresar 15.000 dólares en el Banco de Crédito Español, a nombre de Sotomayor, a cuenta de la adquisición y exportación de dos de las seis tablas en principio previstas. Al cambio en moneda española ello suponía 594.750 pesetas, una cifra cercana a las 700.000 que se había acordado invertir en la adquisición de las seis tablas liquidadas por Arcadio Torres. La cuantía fue muy bien recibida por el Ministerio, que juzgó el arreglo como beneficioso para el Estado.

Por este motivo, desde instancias superiores se resolvió entonces eliminar las trabas para exportar dichas pinturas. Con fecha 19 de abril de 1952 Mont agradecía al director del Museo del Prado su apoyo para llevar a buen fin la citada operación. Todo lo cual era contemplado por el agente como una actuación muy positiva para las relaciones entre EE. UU. y España: "agradecerle su afable ayuda que nos hizo posible adquirir los dos cuadros importantes de Juan de Flandes para América. Hay aquí muy pocas pinturas españolas, pero es grandísimo el interés. Estamos convencidos de que su actitud generoso [sic] en este asunto significará un paso más en profundizar la amistad entre los dos países..."42.

Poco después, el 16 de mayo de 1952, llegó la Orden Ministerial autorizando la exportación de La Anunciación y La Natividad, mientras que las cuatro tablas restantes: Resurrección de San Lázaro, La oración en el huerto, Ascensión de Jesucristo y Pentecostés; serían destinadas al Museo del Prado. El cambio de opinión quedó justificado por las ventajosas condiciones presentadas por Mont. Aquellas dos pinturas, sobre las que, ahora sí, se autorizaba su exportación, pasaron a no considerarse tan relevantes, el argumento para así justificarlo era que su iconografía había sido muy representada en la Historia del Arte y, por otra parte, se estimaba que Juan de Flandes quedaba bien representado en el Museo del Prado con cuatro obras ${ }^{43}$.

Al día siguiente de ser recibida la Orden Ministerial, el director del Museo del Prado, Fernando Álvarez de Sotomayor, escribió a Frederick Mont para informarle de la "beneficiosa solución" que había tenido el asunto; convenía con el anticuario que ello sería positivo para "profundizar la buena amistad" entre ambos países. Sotomayor aceptaba de Mont el ofrecimiento de un lienzo de Iriarte como donación para el Museo del Prado y se mostraba muy agradecido, hasta tal punto que en su despedida señalaba que tal gesto serviría "para que pongamos siempre nuestra mejor voluntad en servirles". Ahora bien, ¿Tenía el Director del Museo del Prado que "poner su mejor voluntad en servir" a un dealer neoyorquino y a su cliente el magnate Samuel H. Kress?, en el contexto de ese clima de relaciones diplomáticas e intereses entre ambos países durante los años cincuenta, parece que sí.

Lo cierto es que finalmente el dinero fue ingresado a nombre del director del Museo del Prado en concepto de donación a la institución, cantidad que pretendía ser destinada a la adquisición de las cuatro tablas de Juan de Flandes restantes. La retirada de dicha cantidad estaba sujeta a una cláusula que subrayaba la condición de exportar las tablas de La Anunciación y La Natividad con destino a Nueva York ${ }^{44}$. Por otra parte, el lienzo de Ignacio Iriarte (1620-1685) Paisaje con

\footnotetext{
${ }^{42}$ Carta de Frederick Mont a Fernando Álvarez Sotomayor, 19/04/1952. Archivo del Museo del Prado, (AMP). Caja 107, Legado 13.06, N1 Exp: 17, N1 Doc: 18.

${ }^{43}$ Traslado de Orden Ministerial de 16 de mayo de 1952, AMP, Caja 107, Legajo 13.06, N. ${ }^{\circ}$ Exp. 17, N. ${ }^{\circ}$ Doc. 15.

${ }^{44}$ Carta del Director del Museo del Prado al Director del Banco Español de Crédito Madrid, 7/04/1952, AMP. Caja 107, Legajo 13.06, n. ${ }^{\circ}$ Exp. 17, n. ${ }^{\circ}$ Doc. 11.
} 
pastores (1665), pasó a engrosar los fondos del Museo del Prado en cuyo catálogo figura como donación de Frederick Mont (1952) en atención a la buena solución de la transacción ${ }^{45}$.

Arcadio Torres, tras los obstáculos iniciales, vio finalmente cerrado con éxito su negocio. El anticuario recibió 200.000 pesetas del Museo del Prado, fraccionadas en dos pagos ${ }^{46}$ por las citadas obras: Resurrección de Lázaro, Oración del huerto, Ascensión, Venida de Pentecostés ${ }^{47}$.Con fecha 16 de mayo de 1952 Torres se dirigió al director de la pinacoteca nacional para precisar la forma de entrega de las citadas pinturas: "Según las instrucciones que tengo recibidas del Sr. Frederick Mont por carta fecha 9 de abril pasado ruego a Vd. que las dos tablas cedidas por ese Museo a las Newhouse Galleries, sean entregadas a la casa Garrouste Transportes Internacionales, la que ha sido encargada por el Sr. Mont para que realice las gestiones de embalaje y transporte de las mismas" "Sotomayor informó a Mont unos días después que las obras habían sido "ya entregadas a la Casa "Garrouste", por orden del Sr. Torres y debían estar ya en camino de su destino", aprovechó la misiva para señalarle que "el cuadro de Iriarte, fechado y firmado, adquirido por Vd. en una galería particular de París que desea ofrecerlo al Museo del Prado, será muy bien acogido aquí en esta casa y muy agradecido además a tan valioso cuadro que nos obliga nuevamente a ponernos a su disposición"49. El 24 de junio de 1952 desde Ferrer y Compañía, consignatarios de transportes internacionales, se confirmó la recepción en el aeropuerto de Barajas del permiso de exportación de las tablas pintadas con destino a EE.UU. ${ }^{50}$.

\section{"americanos, os recibimos con alegría..."}

Aquella visión cómica y amarga de la película Bienvenido Mr. Marshall (Luis García Berlanga, 1953) que da título a este epígrafe, adquirió pleno sentido en buena parte de los tratos, respaldados por la dictadura de Franco, que condujeron a la salida de diversos tesoros artísticos del país durante los años cincuenta. A decir verdad, aquella disposición favorable a satisfacer la demanda norteamericana de antigüedades no era nueva, durante las primeras décadas del siglo XX la salida de obras de arte procedentes de España con destino a EE.UU. había sido extraordinaria ${ }^{51}$; ahora bien, la II República había procurado inaugurar un nuevo tiempo donde la preocupación por este problema, y el deseo de combatirlo, había resultado clave para la promulgación de la Ley de Tesoro Artístico Nacional de 1933, que tenía entre sus principales objetivos impedir la salida de obras de arte del país ${ }^{52}$. Sin embargo, tras la guerra y el periodo de autarquía subsiguiente, tal deseo de complacer las pretensiones de magnates norteamericanos, aun a costa de los propios intereses culturales del país, cobró nuevo impulso. Lo cual ha de ser situado en el horizonte de la política aperturista del régimen de Franco, especialmente tras la firma del convenio bilateral con EE.UU. en 1953. El dictador deseaba salir del aislamiento político y fortalecer su posición internacional sirviéndose para ello del respaldo de la joven potencia ${ }^{53}$. Este nuevo escenario diplomático no solo tuvo su margen de acción en la atracción de inversiones de capital privado norteamericano en España, en el impulso del turismo, o en el establecimiento de las bases militares de EE.UU. en el país, deparó también importantes ecos en la política cultural desde diversas perspectivas.

El caso de la referida exportación de las pinturas de Juan de Flandes, a fin de satisfacer los intereses de Samuel H. Kress, es un buen ejemplo, y no fue el único testimonio. La salida del ábside

\footnotetext{
45 Museo del Prado, número de catálogo P02970.

${ }^{46}$ AMP. Caja 107, Legajo 13.06/ n. ${ }^{\circ}$ Exp.: 17/n. ${ }^{\circ}$ Doc.: 4 y Doc.: 7.

47 Sánchez, 1954. Bermejo, 1962, 1986. 2004. Silva, 2013: 25-43.

${ }^{48}$ AMP. Caja: 107 / Legajo: $13.06 /$ N. ${ }^{\circ}$ Exp.: 17 / N. ${ }^{\circ}$ Doc: 16.

${ }^{49}$ Carta de Fernando Álvarez de Sotomayor a Frederick Mont, 26/05/1952, AMP. Caja: 107 / Legajo: 13.06 / N. ${ }^{\circ}$ Exp.: 17 N. ${ }^{\circ}$ Doc: 20.

${ }^{50}$ AMP. Caja: 107 / Legajo: 13.06 / N. ${ }^{\circ}$ Exp.: 17 N. ${ }^{\circ}$ Doc 21.

51 Merino/Martínez, 2012.

${ }^{52}$ Cabañas/Bolaños, 2014.

${ }^{53}$ Chamorro, 2002. Rosendorf, 2014.
} 
de San Martín de Fuentidueña (Segovia), con destino a The Cloisters, la institución creada por J. D. Rockefeller Jr. (1874-1960), pese a estar declarado monumento nacional, fue el caso más significativo. No hemos de olvidar, tampoco, las facilidades ofrecidas a otros magnates, como Algur Meadows (1899-1978) ${ }^{54}$ en el tiempo en que este estaba forjando su colección de pintura, hoy Meadows Museum de Dallas, por señalar apenas algunos ejemplos reveladores. Tal vez por ello, aquella apreciación de Rosendorf al analizar el clima de las relaciones entre ambos países, como una forma de venta de España a Estados Unidos por parte de Franco, adquiera sentido cuando pasamos a analizar el tema que nos ocupa ${ }^{55}$.

No hay duda de que tal contexto favoreció los negocios de Arcadio Torres. Cierto es que él llevaba trabajando en la compra, venta y exportación de antigüedades desde la década de los años veinte. Había fraguado el éxito de su negocio gracias a sus relaciones con otros anticuarios que dominaban el tráfico de obras de arte con destino a Estados Unidos. Aquella trama del comercio de arte funcionaba gracias a una tupida red piramidal donde los grandes agentes y anticuarios internacionales se servían de estos comerciantes locales para proveerse de obras y servirse de sus contactos a la hora de adentrarse en templos, conventos, palacios episcopales, colecciones particulares..., todo ello a fin de descubrir piezas susceptibles de ser adquiridas. Tras el fallecimiento de Arthur Byne en 1935 y Raimundo Ruiz en 1954, Torres decidió ofertar por sí mismo sus obras a posibles clientes americanos.

El anticuario había ido avanzando posiciones en los círculos de la élite social y cultural. En 1939 acompañó al embajador de los EE UU, Alexander W. Weddel, en su visita a Palencia. Durante el curso de la misma visitaron la catedral, donde Torres y el director del periódico El día de Palencia se fotografiaron con el diplomático, junto con la esposa y secretario de este ${ }^{56}$. En 1956, Torres hizo lo propio con el hispanista Walter S. Cook (1888-1962) en su recorrido por Castilla. Juntos visitaron, por ejemplo, Santo Domingo de Silos, la catedral de Burgos, San Salvador de Oña, San Andrés de Arroyo..., quedó constancia de ello en las misivas que Cook remitió a James J. Rorimer (1905-1966), director del Metropolitan Museum of Art de Nueva York. Además de postales de algunos de dichos monumentos, como el claustro de $\mathrm{Silos}^{57}$, el hispanista le hizo llegar algunas instantáneas de tal recorrido artístico en compañía de Torres [fig. 6]. Apenas unos meses después se formalizaría el acuerdo que llevó a la salida del país del ábside románico de San Martín de Fuentidueña (Segovia) [fig. 7].

\section{Tras la exportación del ábside de San Martín de Fuentidueña (Segovia)}

Durante las operaciones que precedieron a la exportación de dicho conjunto arquitectónico, nuestro protagonista actuó como agente que procuró satisfacer el deseo de J. D. Rockefeller Jr. (1874-1960) de hacerse con un ábside románico con destino a su fundación: The Cloisters, sección medieval del Metropolitan Museum of Art de Nueva York.

En diversos trabajos ha sido tratada esta operación, que acabó materializada en 1957 mediante un acuerdo entre el Estado español y el citado museo. Dicho acuerdo fue alcanzado en el marco de unas negociaciones que facilitaron el desmontaje y traslado a Nueva York del citado ábside para ser instalado en el museo The Cloisters. Esto fue posible gracias a su intercambio por un conjunto de pinturas de la primera mitad del siglo XII, con escenas cinegéticas, procedentes de la decoración mural de San Baudelio de Berlanga; pinturas que habían sido vendidas y exportadas en la década de los años veinte de la pasada centuria ${ }^{58} y$ retornaron a España en ese momento con

\footnotetext{
${ }^{54}$ Jordan, 1999: 343-352. Patton, 1997: 258-266.

55 Rosendorf, 2014.

56 "La visita a Palencia del embajador de los EE UU”, El día de Palencia, 22/06/1939.

${ }_{57}$ Metropolitan Museum of Art Archives, Nueva York (MMAA). James J. Rorimer Records, Box 12, fol.2.

${ }^{58}$ Martínez, 2008, t. I: 213-276.
} 


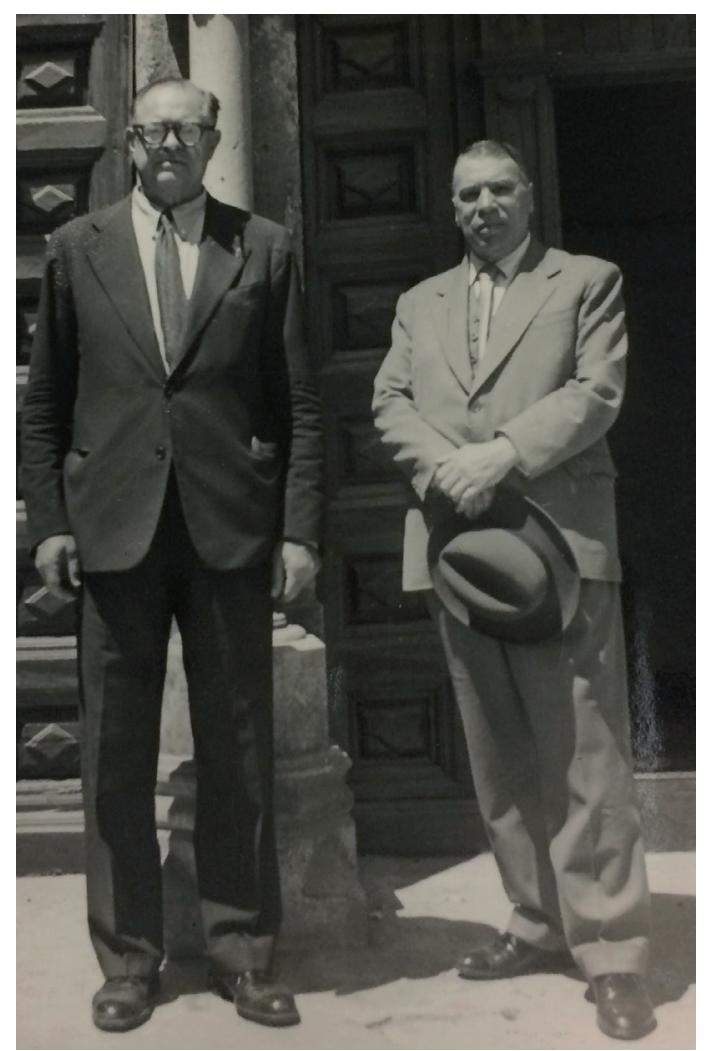

Fig. 6. Arcadio Torres junto con W. S. Cook en la catedral de Burgos. Archivo del Metropolitan Museum of Art, Nueva York. destino al Museo del Prado ${ }^{59}$. Ahora bien, además de la labor desarrollada en esta operación por Carmen Gómez-Moreno para la institución neoyorquina $^{60}$, destacada en otros estudios ${ }^{61}$, deseamos poner de relieve en este momento a nuestro protagonista, que actuó en la sombra para hacer posible tal exportación.

La correspondencia cruzada entre Arcadio Torres y el director del Metropolitan Museum of Art de Nueva York, James J. Rorimer, así como con la conservadora de la institución, Margaret B. Freeman, resulta reveladora en este sentido. De ella se desprende que las negociaciones iniciales para la adquisición y exportación del edificio se habían llevado a cabo entre Rorimer y los agentes que en España le habían ofrecido la posibilidad de hacerse con tal ábside románico: Raimundo Ruiz ${ }^{62}$ y Arcadio Torres. Ambos habían tratado la posibilidad de venta del ábside con el alcalde de Fuen-

${ }_{59}$ Merino, 1997: 24-27. Merino/Martínez, 2012: 106110. Cortés/Otero/Esteban/Marín, 2016. Cortés/Esteban/ Marín, 2017: 68-77.

${ }^{60}$ Gómez-Moreno, 1961: 61-85.

${ }^{61}$ Merino, 1997: 24-27. Merino/Martínez, 2012:106110.

${ }^{62}$ Martínez, 2011: 49-87.

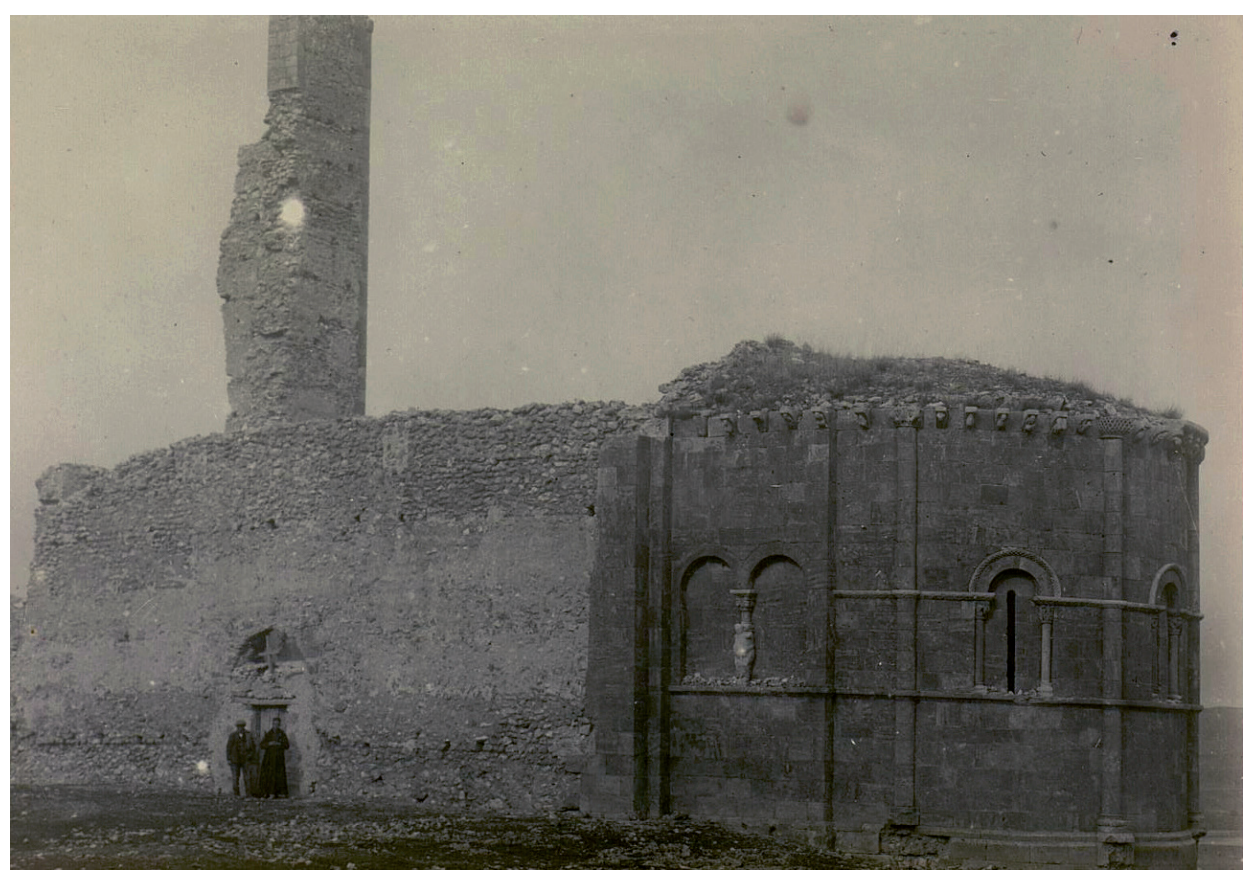

Fig. 7. Ábside de San Martín de Fuentidueña en su emplazamiento original. Francisco Rodríguez Marín, Catálogo Monumental de España. Segovia, t. IV. 1923 (sin publicar). CSIC, Madrid. 
tidueña y con el obispo de Segovia, con quienes negociaron tal adquisición y traslado a EE.UU. Ruiz falleció en 1954 y Torres siguió al tanto de la operación. Aunque la disposición de aquellas partes fue buena, lo cierto es que el escollo jurídico que suponía la circunstancia de que tal edificio estuviera declarado monumento nacional, motivó que Torres lo tuviera difícil para conseguir el permiso de exportación. Fue en ese momento cuando el régimen de Franco tomó las riendas de la operación y allanó el camino para que semejante exportación fuera posible a fin de complacer los deseos de J. D. Rockefeller Jr. y del Metropolitan Museum of Art de Nueva York. Desde ese momento la labor del anticuario fue prescindible, puesto que la negociación última se estableció entre el propio museo y las altas instancias del Estado - favorecidas por el clima diplomático alentado por el marco de las relaciones bilaterales antes señaladas-.

El 8 de julio de 1957, cuando Carmen Gómez-Moreno estaba viajando a España a fin de ultimar el traslado del ábside, Rorimer escribió a Arcadio Torres para decirle que si todo iba bien recibiría un pago importante que compensaría todas sus molestias y los gastos que había asumido a lo largo de la negociación. Destinaría fondos para él "como le había prometido en principio", "some five thousand dollars", pues entendía lo mucho que había ayudado al gobierno español, a la embajada y a Carmen Gómez-Moreno para superar los problemas:

You will be pleased to know that Sra. Carmen Gómez-Moreno is leaving by plane to be in Madrid by Monday next. She will have a check and receipts for the interested parties, including a check which we are sending you on account. You will have certain expenses at the present time, and at the end of the negotiations which I now consider complete we will have additional funds for you as I promised originally. I am suggesting that if all goes well, there be an additional payment to you some five thousand dollars. It is very difficult for us at this end to figure out what your expenses will be, and how much part you will play in helping the Spanish Government and the Embassy and Miss Gómez-Moreno to work out the various details. She will keep me informed from time to time, and I will come over if necessary ${ }^{63}$.

Torres contestaba unos días después al director del Metropolitan Museum agradeciéndole el presente recibido de su parte, al tiempo que le expresaba la gran satisfacción que le producía servirle, pues en este proyecto había revelado su gran sensibilidad y amor al arte románico, motivo por el cual para él había sido un gran placer asistirle:

I received your gift, which is far more tan I deserve for it, is a great satisfaction to me to serve you. Whenever I may assist your Project, in which is evident your fine sesibility and love of Romanesque art, i would do it with great pleasure.

On the 22nd I was in Fontiduena [sic] with the Mayor and further in Segovia with the Prelate and in Madrid with the Senorita [sic] Carmen, through whose mediation I send you expressions of thanks from the Prelate and the Mayor $[\ldots]^{64}$.

Carta que había sido traducida a James J. Rorimer pues lo cierto es que Torres acostumbraba a dirigirse a sus clientes americanos en español o francés, en alguna ocasión incluso llega a disculparse por ello, pues reconoce no hablar inglés ${ }^{65}$.

\footnotetext{
${ }^{63}$ Carta de J. J. Rorimer a Arcadio Torres,08/06/1957. MMAA. James J. Rorimer Records, Box 12, fol. 1.

${ }^{64}$ Traducción de carta dirigida por Arcadio Torres a James J. Rorimer, 26/07/1957.MMAA, James J. Rorimer Records, Box 12, fol. 1.

${ }_{65}$ Carta de Arcadio Torres a J. J. Rorimer, redactada en francés, 6/11/1958 y recibida en Nueva York 10/11/1958. MMAA, James J.Rorimer Records, Box 12, fol. 1.
} 


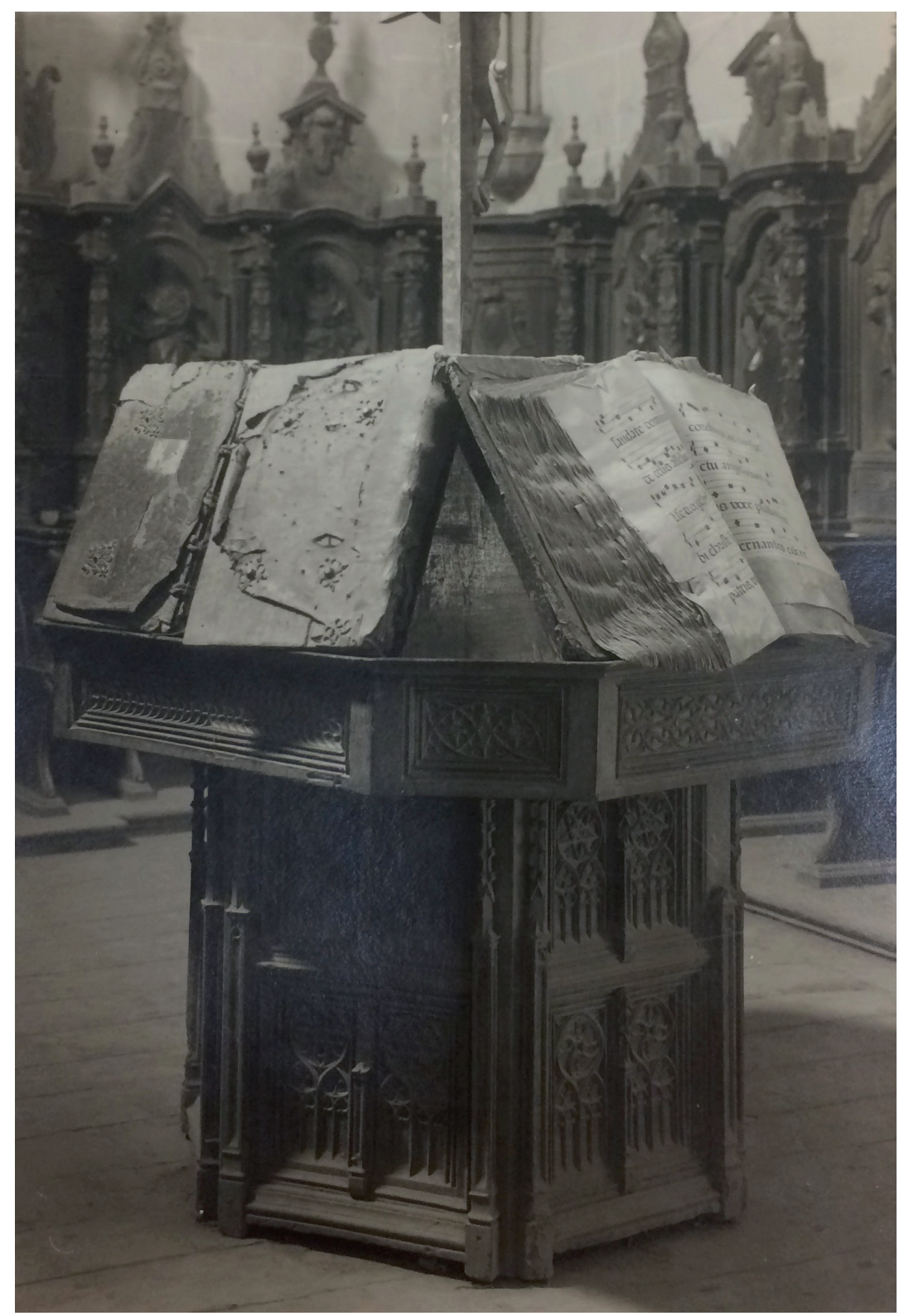

Fig. 8. Facistol de Santoyo (Palencia). Imagen remitida por Arcadio Torres a James J. Rorimer. Archivo del Metropolitan Museum of Art, Nueva York.

\section{Otros tratos con el Metropolitan Museum of Art de Nueva York: el facistol que no fue y el templo de Santa Eufemia de Cozuelos (Palencia)}

Con fecha 6 de noviembre de 1958, Arcadio Torres se dirigió nuevamente al director del Metropolitan Museum of Art para ofrecerle "una imagen en piedra blanca caliza y un mueble gótico fácil de adquirir", a fin de que este le transmitiera sus impresiones al respecto. La conservadora de la institución, Margaret B. Freeman respondió a Torres en nombre de su jefe. La institución se mostraba interesada por el mueble, un facistol [fig. 8], y quería conocer el precio aproximado del mismo en caso de que pudiera ser adquirido para el museo. Sin embargo, no reveló interés alguno por la Madonna en piedra. Es importante advertir que "el mueble gótico" que Torres ofrecía era el facistol del coro de la iglesia de San Juan Bautista de Santoyo (Palencia), del cual había 
remitido fotografías acompañando su misiva ${ }^{66}$. En este caso, el negocio no prosperó, pues la obra, afortunadamente, sigue en su emplazamiento original. Las dificultades halladas por Torres en esta operación le llevaron a buscar una alternativa, y poco menos que a tratar de dar gato por liebre al museo neoyorquino.

Con fecha 16 de febrero de 1959 el anticuario palentino remitía nuevamente una misiva a Rorimer a propósito de un "púlpito del siglo XV" $\mathrm{XV}^{67}$. El asistente del director le contestó que en ese momento aquel se encontraba de viaje por el norte de Europa y tenía el asunto en temas pendientes, no se olvidaba de él, pero lo abordarían más adelante; en cualquier caso, aprovechó la ocasión para consultarle el precio del mismo ${ }^{68}$. El 29 de octubre de 1959 Arcadio Torres informaba nuevamente sobre el "mueble-púlpito" cuyo precio era de 100.000 pesetas; se mostró a la espera de poder adquirirlo para el Metropolitan si este resultaba de interés para su director ${ }^{69}$. Finalmente, Rorimer resolvió aceptar por 100.000 pesetas el citado mueble, suma a la cual se sumarían los gastos de Torres, así como los derivados de la expedición y seguro de la obra. Solicitaba al anticuario, además, que lo remitiera a través de Tice and Lynch, 21 Pearl Street New York, $4^{70}$.

Queda documentada la adquisición, firmada por Margaret B. Freeman, con fecha 30 de noviembre de 1959 por el Metropolitan Museum of Art de "One lectern, walnut, six-sided with carved panels Spanish, late XV Century" por 100.000 pesetas más gastos derivados del empaquetado, traslado y seguro. Pieza vendida por "Arcadio Torres, V. Calderón, 5, Palencia, España" y destinada a The Cloisters. Sin embargo, en marzo del año siguiente Rorimer expresó su enojo pues aún estaba esperando la parte superior del facistol, afirmaba que solo había llegado la parte inferior, pero no aquella que sirve de apoyo a los libros, por eso le pedía explicaciones acerca de lo que había ocurrido al respecto. Le informaba, además, que en el mes de julio viajaría a España y esperaba verle entonces, momento en el que le daría información más precisa "acerca de sus planes"

Las dificultades sobre esta venta y las dudas en el Metropolitan, pues la pieza en cuestión seguía sin llegar a Nueva York, no desanimaron al agente, quien días después, el 19 de mayo de 1960 desvió la atención de aquel comprometido asunto ofreciendo a Rorimer otra obra completamente diferente que pensaba podía resultar más que interesante para The Cloisters: el templo románico de Santa Eufemia de Cozuelos (Palencia), que vendía por un millón de pesetas. Arcadio Torres escribió dicha carta nada más recibir la propuesta del propietario de la finca de Santa Eufemia, Fernando Díaz de Bustamante:

Es posible que me decida a vender mi finca de Santa Eufemia, y me interesaría saber si a sus amigos del museo de Nueva York les pudiera seguir interesando los siete capiteles de la iglesia, para en ese caso no comprometerlos en la venta, en atención a ellos y a usted, que tuvo la amabilidad de acompañarlos en sus visitas. Le agradeceré, pues, que me informe. También se me ocurre pensar que, quizá, al futuro comprador de mi explotación agrícola no le interese aquella hermosa iglesia románica, pues le bastaría con una pequeña capilla, y pudiera venderla entera para su traslado al mismo destino u otro distinto, donde cumpliera una hermosa función para el culto... ${ }^{72}$.

La oferta, como vemos, era bien por siete capiteles de la iglesia, o incluso por el templo completo [fig. 9], pero lo cierto es que los tratos entre Torres y Rorimer no se encontraban en el mejor momento, todo ello a tenor de los dudosos manejos del agente en torno a la operación

${ }^{66}$ Carta dirigida por Margaret B. Freeman, a Arcadio Torres, 13/11/1958. MMAA, James J.Rorimer Records, Box 12, fol. 1 .

${ }^{67}$ Carta de Arcadio Torres a Rorimer, 16/02/1959, recibida en el Metropolitan el 24/02/1959. MMAA, James J.Rorimer Records, Box 12, fol. 1.

${ }^{68}$ Carta del Executive Assitant de J. J. Rorimer a Arcadio Torres, 18/06/1959.MMAA, James J.Rorimer Records, Box 12, fol. 1.

${ }^{69}$ Carta de Arcadio Torres a Rorimer, 29/10/1959, recibida en el Metropolitan el 2/11/1959.MMAA, James J.Rorimer Records, Box 12, fol. 1.

${ }^{70}$ Carta de J. J. Rorimer a Arcadio Torres fechada el 10/11/1959.MMAA, James J.Rorimer Records, Box 12, fol. 1.

${ }^{71}$ Carta de J. J. Rorimer a Arcadio Torres, 7/03/1960, MMAA, James J.Rorimer Records, Box 12, fol. 1.

${ }^{72}$ Carta de Fernando Díaz de Bustamante a Arcadio Torres, 17/03/1960 y remitida por este último a J. J. Rorimer. MMAA, James J.Rorimer Records, Box 12, fol. 1. 


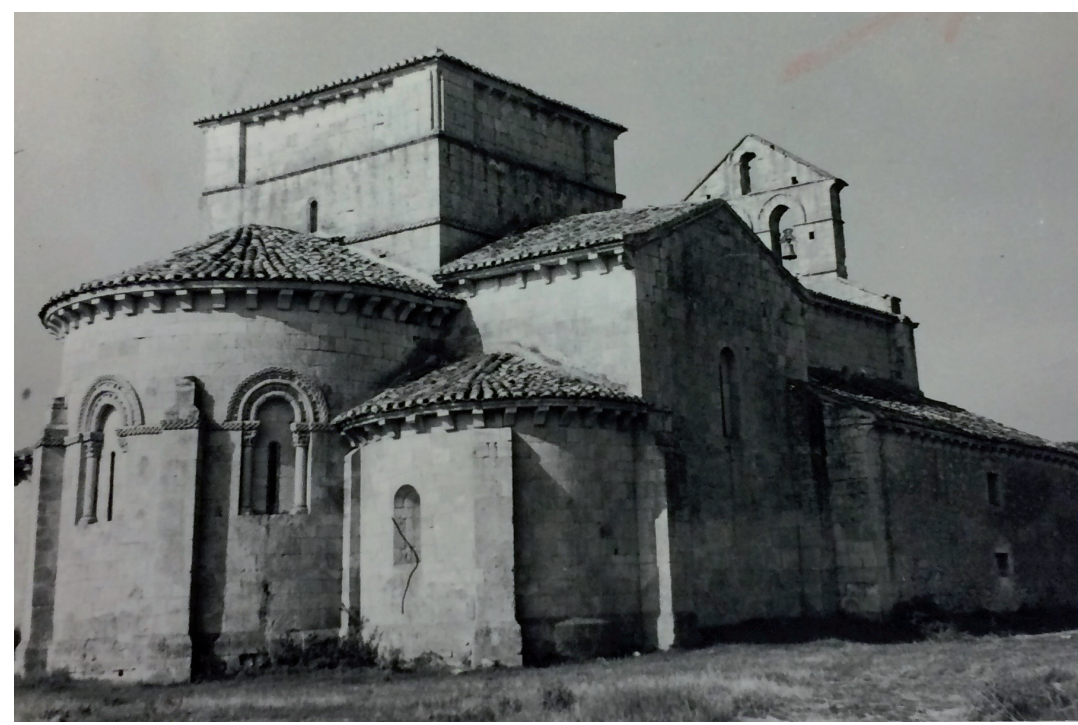

Fig. 9. Santa Eufemia de Cozuelos (Palencia). Imagen remitida por Arcadio Torres a James J. Rorimer. Archivo del Metropolitan Museum of Art, Nueva York.

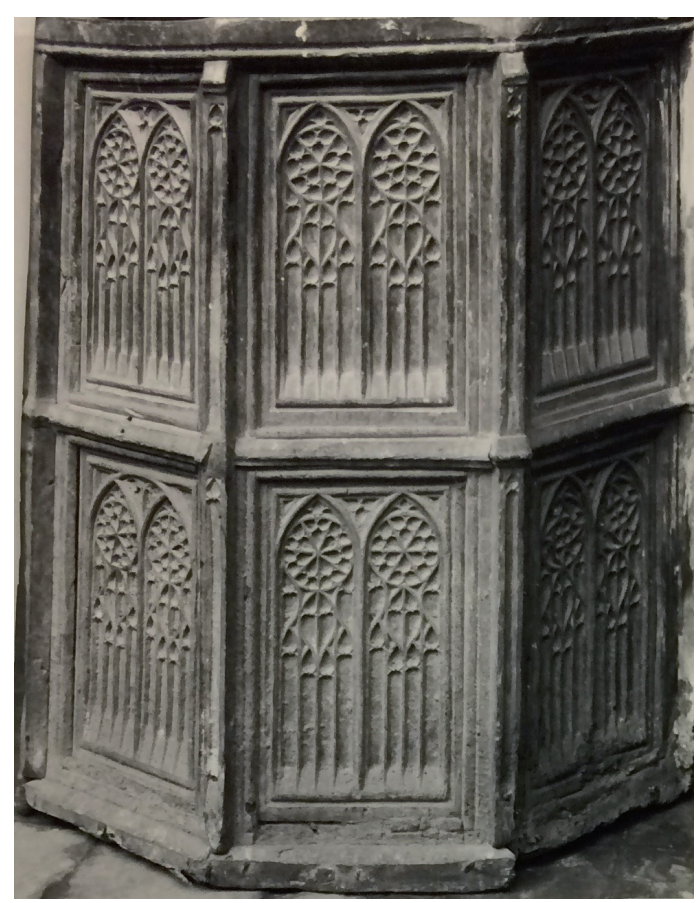

Fig. 10. Púlpito de Dueñas (Palencia). Imagen remitida por Arcadio Torres a James J. Rorimer. Archivo del Metropolitan Museum of Art, Nueva York. "facistol". En una misiva remitida por el agente palentino parece aclararse semejante entuerto; en realidad, Arcadio Torres no había enviado a Rorimer un facistol, sino un púlpito, usado eso sí como pie de facistol [fig. 10]. De ahí que aludiera a tan ambigua denominación en sus cartas anteriores: "mueble gótico", "púlpito" o "púlpito-facistol". A fin de no perder la inversión, el anticuario salió del paso de una forma bastante curiosa; en primer lugar, aclaró que él no hablaba inglés y tenía que servirse de un traductor que quizá en ocasiones cometía errores y, en segundo lugar, explicó a Rorimer que en realidad la pieza en cuestión era un púlpito fácilmente transformable en facistol. A su juicio, no había problema alguno, incluso le adjuntó un boceto en el cual le mostraba cómo los paneles podían ser desmontados a fin de componer un facistol [fig. 11]. Ahora bien, el convertible ingeniado por el agente para reparar la imposibilidad de enviar la pieza que en un primer momento había ofrecido, no fue aceptado. Rorimer tiró de ironía al comenzar su respuesta: "Al menos se ha tomado tiempo para hablar del facistol". Ahora bien, su contestación fue firme:

Although you have from time to time spoken of a pulpit, it was a photograph of a lectern that you sent to us and it was a lectern that we agreed to purchase but have not received. Unless the piece you have sent us is the base of a lectern or bookstand and you can supply the top part that originally belonged to it, we are not interested and will return it to you. If posible, I will try to see you when I am in Spain in July ... ${ }^{73}$.

${ }^{73}$ Carta de J. J. Rorimer a Arcadio Torres, 25/03/1960. MMAA, James J. Rorimer Records, Box 12, fol. 1. 

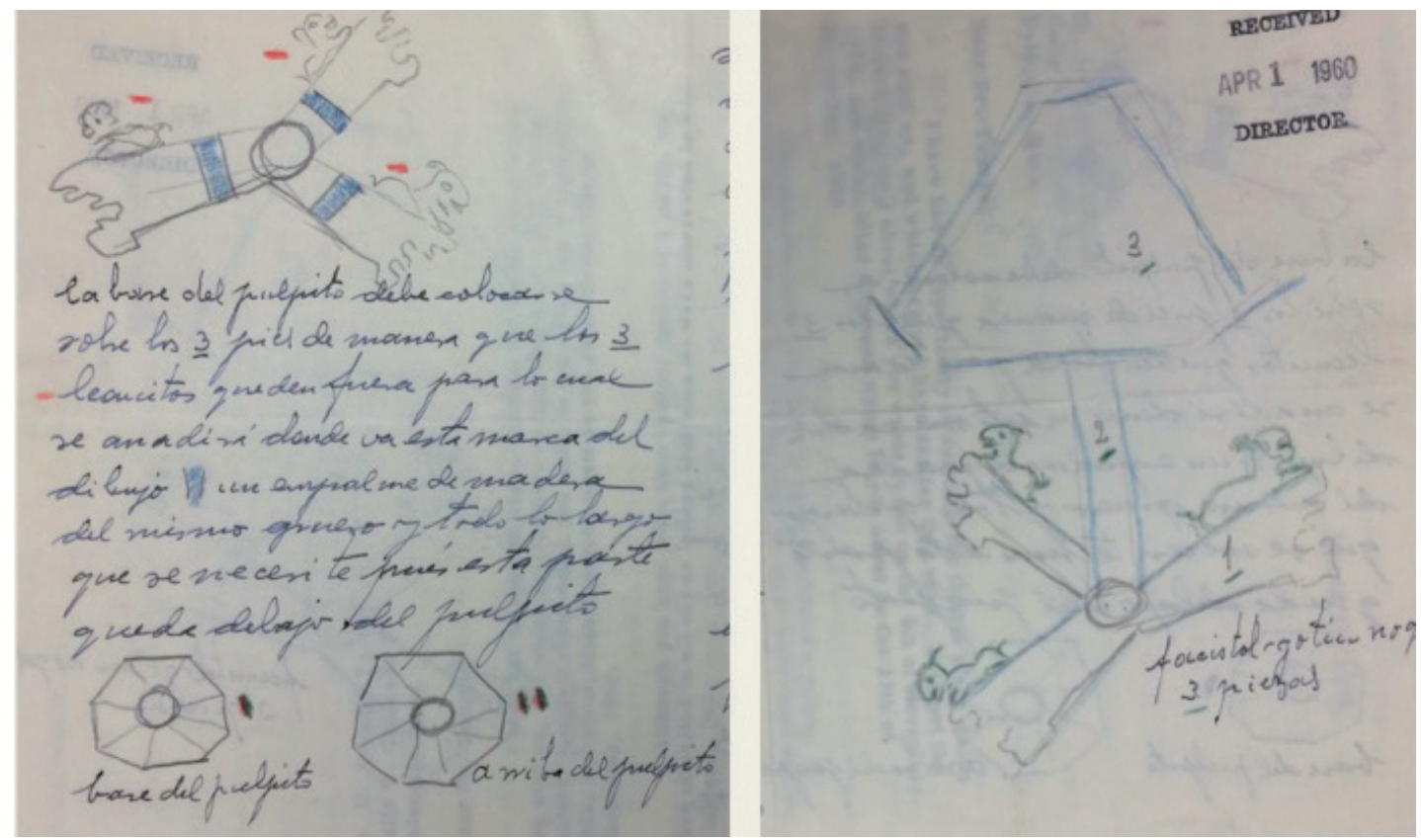

Fig. 11. Dos detalles de la misiva de Arcadio Torres a James J. Rorimer en la que, con dibujos explicativos, le muestra la facilidad de transformar el púlpito enviado a Nueva York en un facistol. Archivo del Metropolitan Museum of Art, Nueva York.

Días después, con fecha 3 de abril de 1960, Torres aclaró el problema: las negociaciones para hacerse con el facistol de Santoyo resultaron imposibles, por eso le envió el púlpito de Dueñas (Palencia), con la idea de que pudiera transformarlo en un facistol. Rogaba al norteamericano que le disculpara por el trastorno que esto le hubiera podido ocasionar y olvidara todo el malentendido. Como Rorimer le había ofrecido una segunda "donación" por San Martín de Fuentidueña, le pedía le remitiera un cheque por 1.666 dólares a fin de cubrir los gastos de exportación del púlpito en cuestión, a nombre de Josefina Fernández Lomana, su cuñada, C. Gobernador 6, Madrid. Como respuesta a este acto de generosidad, totalmente voluntario, él no pedía nada más, podía quedarse con el púlpito como regalo. Además, Torres se ofrecía a presentarle al obispo de Palencia para que comprobara por él mismo lo que había pagado por el púlpito, y cómo el problema había venido porque en realidad no comprendía del todo bien sus cartas. Estaba resignado a sufrir las consecuencias económicas de todo ello, y recibir de vuelta la obra no haría más que agravar estas. De todos modos, esto no era lo que más le preocupaba, sino perder su amistad ${ }^{74}$. Rorimer contestó no entender su oferta, entre otras cosas porque no quedaba nada pendiente de pagarle a costa de la operación de Fuentidueña, habida cuenta que las negociaciones se cerraron en última instancia directamente con el Gobierno español, para que no hubiera lugar a dudas por su parte le respondió en español ${ }^{75}$.

Dada la situación, el anticuario hubo de dar por perdido el negocio; se ofreció a devolver la cifra pagada en pesetas cuando viajara a España en julio. Mostró su satisfacción con la cantidad ingresada a cuenta de Fuentidueña y rogó fuera aceptado el púlpito como gesto de agradecimiento. Eso sí, le recordó que aún no le había ofrecido respuesta alguna a propósito de los capiteles - aquellos de Santa Eufemia de Cozuelos, que creía podían ser de interés para el museo, había

${ }_{74}$ Carta de Arcadio Torres a James J. Rorimer, 3/04/1960.MMAA, James J. Rorimer Records, Box 12, fol. 1.

${ }^{75}$ Carta de J. J. Rorimer a Arcadio Torres, 19/04/1960.MMAA, James J. Rorimer Records, Box 12, fol. 1. 
llegado incluso a ofrecer el templo entero-, algo que creía podrían tratar cuando el norteamericano visitara el país en verano ${ }^{76}$.

Efectivamente, el 8 de julio de 1960 Arcadio Torres se encontró con James J. Rorimer en Madrid y abordaron, entre otras cosas, el tema del púlpito-facistol. El anticuario insistió en que la obra era del Metropolitan Museum y dado que Rorimer había expresado su intención de no conservarla como un regalo, eran libres para venderla. Torres expresó que podían hacer con ella lo que desearan ${ }^{77}$. Imaginamos que hubieron de tratarse otros asuntos de interés para el Metropolitan Museum of Art, y para nuestro protagonista. Tal impresión suscita la carta que poco tiempo después remitió el anticuario a su cliente neoyorquino:

Distinguido amigo: Recibí su postal de Toulouse y he venido a Zaragoza para ver de complacerle. En principio me dicen que es necesario presentar una petición por escrito al Señor Deán y después vencer las dificultades que no serán pocas.

Así pues V. Me dirá el número de tapices si es uno ó son dos y el precio a aprecer [sic] por ellos. Se harán todas las gestiones necesarias a fin de alcanzar un buen resultado ${ }^{78}$.

Torres pensaba que seguiría haciendo negocios con Rorimer, quizá adquiriendo para él unos tapices de la catedral de Zaragoza, pero lo cierto es que había acabado con su paciencia. Al menos así cabe interpretar de sus contundentes palabras a fines de septiembre de ese mismo año. No parecía estar interesado en nada que este pudiera ofrecerle. El enfado del director del Metropolitan no deja lugar a dudas:

\section{Dear Sr. Torres}

You are incomprehensible. Mr. Hoving and I told you that you would receive no further payment for your eccentric handling of the wooden "lectern" and I further told you that we will make no proosals to purchase important Works of art at this time. How in heaven's name do you expect me to give an opinion from your description of the stonework? I just can't understand you. Yours sincerely, James J. Rorimer, Director ${ }^{79}$.

Lo cual hubo de ser definitivo en su relación epistolar, y no era para menos, el agente le había estado mareando a propósito de una operación en la cual en realidad pretendía darle gato por liebre, algo que el director de la institución obviamente no iba a asumir, por mucho que Torres buscara nuevas obras que ofrecerle. Lo cierto es que el modo de desenvolverse en tan torpe negociación parecía haberle cerrado las puertas para futuras operaciones con la institución. Había cumplido su labor como agente y mediador en los trámites que precedieron a la transacción en torno al ábside de San Martín de Fuentidueña, como tal se reconoció, pero desde el momento en que la negociación se cerró con las altas instancias del Estado, el papel de Torres quedó minimizado. Puede que en España siguiera haciendo gala de sus clientes y "amigos americanos", y por ello le siguieran llegando ofertas de propietarios de obras de arte dispuestos a vender en aquel mercado, pero al menos en lo que al Metropolitan Museum of Art se refiere, no lo iba a tener fácil a partir de ese momento.

\section{Consideraciones finales}

Arcadio Torres vivió en ese tiempo de bonanza del tráfico de obras de arte con destino a EE.UU., supo manejarse entre esa cumplida red de agentes nacionales e internacionales tejida desde las primeras décadas del siglo XX, pero también en el entorno eclesiástico, donde halló su

\footnotetext{
${ }^{76}$ Carta de Arcadio Torres a J. J. Rorimer, 27/04/1960.MMAA, James J. Rorimer Records, Box 12, fol. 1.

77 Memorandum, 7/09/1960. MMAA, James J. Rorimer Records, Box 12, fol. 1.

${ }_{78}$ Carta de Arcadio Torres a J. J. Rorimer, 3/08/1960.MMAA, James J. Rorimer Records, Box 12, fol. 1.

${ }^{79}$ Carta de J. J. Rorimer a Arcadio Torres, 19/09/1960.MMAA, James J. Rorimer Records, Box 12, fol. 1.
} 
principal fuente de provisión de bienes artísticos. Su trabajo como conseguidor de obras fue importante, así lo ilustran algunos de los ejemplos tratados. Desde luego el viento sopló a su favor: como anticuario local que abasteció la red internacional de obras de arte con destino a EE.UU. durante los años veinte, un periodo de intensa demanda de antigüedades españolas en aquel país; a lo largo de la posguerra supo obtener provecho de la precaria situación de templos y conventos; mientras que en la década de los cincuenta su negocio contó con el ventajoso ambiente creado por las relaciones bilaterales entre España y Estados Unidos. Nuestro protagonista aspiró a prosperar gracias a los dólares, como en la citada película de Berlanga, y llegó a conseguirlo, aunque fuera a costa de liquidar diversos vestigios del patrimonio artístico del país.

\section{BIBLIOGRAFÍA}

Aguado, Alejandro Luis / Torres Martín, Arcadio (1976): Museo de la Iglesia Parroquial de Santa Eulalia de Paredes de Nava. Madrid: Ministerio de Educación Nacional, Dirección General de Bellas Artes.

Almaraz, Enrique (1900): "Real Monasterio de San Andrés del Arroyo (Palencia)". En: Boletín de la Real Academia de la Historia, 36, pp. 210-229.

Álvarez Reyero, A. (1898): Crónicas episcopales palentinas. Palencia: Abundio Z. Menéndez.

Bermejo, Elisa (1962): Juan de Flandes. Madrid: Instituto Diego Velázquez CSIC.

Brans, Jan V. L (1953): “Juan de Flandes, pintor de la Reina y de Castilla”. En: Clavileño, 4, 21, pp. 29-32.

Cabañas Bravo, Miguel / Bolaños Atienza, María (eds.) (2014): En el frente del arte. Ricardo de Orueta (1868-1939), Madrid: Acción Cultural Española.

Chamorro Chapinal, Alfredo (2002): Los convenios hispano-norteamericanos de 1953 en el contexto político-estratégico de la época. Negociación, desarrollo y consecuencias, (Tesis Doctoral). Madrid: Universidad Complutense.

Cortés Álvarez de Miranda, Javier (1999): “Algunos datos sobre el Santuario de la Virgen del Valle en Saldaña”. En: Publicaciones de la Institución Tello Téllez de Meneses, Palencia, 70, pp. 491-492.

Cortés Messeguer, Luis Cortés / Otero Pailos, Jorge / Esteban Chapapría, Julián / Marín Sánchez, Rafael (2016): Patrimonio arquitectónico español en Estados Unidos: el caso de San Martín de Fuentidueña (Segovia). Valencia: Universidad Politécnica de Valencia.

Cortés Messeguer, Luis / Esteban Chapapría, Julián / Marín Sánchez, Rafael (2017): “Desmontaje y traslado del ábside de Fuentidueña. Experiencia y método en el arquitecto Alejandro Ferrant”. EGA, 22, 29, pp. 68-77.

Estrada Nérida, Julio (2007): "Noticias y documentos sobre la capilla mayor e iglesia de San Lázaro en Palencia". En: Publicaciones de la Institución Tello Téllez de Meneses, 78, pp. 295-342.

Franco Mata, Ángela (2013): “El Museo Arqueológico Nacional y la colección de arte románico”. En: Huerta, Pedro Luis: La diáspora del románico hispano. De la protección al expolio. Aguilar de Campoo: Fundación Santa María la Real, pp. 132-179.

Gallego Lorenzo, Josefa (1989): "San Martín de Tours, S. Marcial de Limoges y Santiago en el llamado frontal de la catedral de Orense". En: Los caminos y el arte, Actas del VI Congreso Español de Historia del Arte, vol. III, Santiago de Compostela, 1989, pp. 61-69.

García Guinea, Miguel Ángel (1959): "La iglesia románica de Santa Eufemia de Cozuelos, Palencia”. En: Archivo Espanol de Arte, 32, 128, pp. 295-132.

Gaya Nuño, Juan Antonio (1958): La pintura española fuera de España; historia y catálogo. Madrid: Espasa-Calpe.

Gómez-Moreno, Carmen (1961): "El ábside de San Martín de Fuentidueña”. En: BSAA, 27, pp. 61-85.

Gutiérrez Pajares, María Teresa (1993): El monasterio cisterciense de San Andrés del Arroyo. Palencia: Diputación Provincial de Palencia.

Hand, John Oliver / Wolff, Martha (1986): Early Netherlandish Painting. Washington: National Gallery of Art.

Jordan, William B (1999): “Algur Meadows. Un recuerdo personal”. En: Goya, 273, pp. 343-352.

Kagan, Richard (2013): "El marqués de Vega-Inclán y el patrimonio artístico español: ¿protector o expoliador? En: Nuevas contribuciones en torno al mundo del coleccionismo de arte hispánico en los siglos XIX y XX. Gijón: Trea, pp.193-203.

Martín González, Juan José / Urrea, Jesús (1977): Inventario artístico de Palencia y su provincia. t. I. Madrid: Ministerio de Educación y Ciencia.

Martínez Monedero, Miguel (2010): “Anselmo Arenillas y la segunda zona monumental (1940-1958)”. En: García Cuetos, Pilar / Almarcha Núñez-Herrador, María Esther / Hernández Martínez, Ascensión, (coords.): Restaurando la Memoria. España e Italia ante la recuperación monumental de posguerra. Gijón: Trea, pp. 119-154.

Martínez Ruiz, María José (2008): La enajenación del patrimonio en Castilla y León (1900-1936). Salamanca: Junta de Castilla y León. t. I.

Martínez Ruiz, María José (2011): "Raimundo y Luis Ruiz. Pioneros del mercado de antigüedades españolas en EE UU”. En: Berceo, 161, pp. 49-87. 
Martínez Ruiz, María José (2018): "Patrimonio de Valladolid emigrado". En: Conocer Valladolid 2016. X Curso de Patrimonio Cultural. Valladolid: Real Academia de Bellas Artes de la Purísima, pp. 255-285.

Menéndez Robles, María Luisa (2006): El Marqués de la Vega Inclán y los orígenes del Turismo en España. Madrid: Ministerio de Industria, Turismo y Comercio.

Merino de Cáceres, José Miguel (1997): "San Martín de Fuentidueña. Cuarenta años de exilio". En: Restauración \& Rehabilitación, 9, pp. 24-27.

Merino de Cáceres, José Miguel / Martínez Ruiz, María José (2012): La destrucción del patrimonio artístico español: W. R. Hearst "el gran acaparador". Madrid: Cátedra.

Navarro García, Rafael (1939): Catálogo monumental de la provincia de Palencia. III. Partidos de Cervera de Río Pisuerga y Saldaña. Palencia: Diputación Provincial de Palencia.

Pardo Fernández, María Antonia (2019): “Anselmo Arenillas Álvarez y su contribución al legado arquitectónico medieval en la España franquista”. En: Payo Hernández, René Jesús / Martín Martínez de Simón, Elena / Matesanz del Barrio, José / Zaparaín, María José (eds.): Vestir la arquitectura: XXII Congreso Nacional de Historia del Arte. Burgos: Universidad de Burgos, pp. 1457-1462.

Patton, Pamela A. (1997): “'El Prado en la Pradera'. Arte español en el museo Meadows (Dallas, Texas)”. En: Goya, 257, pp. 258-266.

Pérez Calvo, Aderito (2003): Cuenca de Campos ayer. Valladolid: Diputación Provincial de Valladolid, 2003, p. 111.

Requejo Alonso, Ana Belén (2004): "La investigación en un museo: biografía del conjunto de esmaltes de Limoges de la Catedral de Ourense”. En: Porta da aira: revista de historia del arte orensano, 10, p. 269.

Revilla Vielva, Ramón (1948): Catálogo Monumental de la Provincia de Palencia. Partidos de Carrión de los Condes y Frechilla. Palencia.

Revilla Vielva, Ramón (1951): Catálogo Monumental de la Provincia de Palencia. Partidos de Astudillo y Baltanás, t. I.

Revilla Vielva, Ramón (1951): Catálogo Monumental de la provincia de Palencia, 1. Partidos de Astudillo y Baltanás. Palencia: Diputación Provincial de Palencia.

Revilla Vielva, Ramón / Navarro García, Rafael (1948): Catálogo Monumental de la Provincia de Palencia 2. Carrión de los Condes y Frechilla. Palencia: Diputación Provincial de Palencia.

Revilla Vielva, Ramón / Torres Martín, Arcadio (1951): "Calabazanos a la vista: la Reina Católica y los Manrique. Nuevos Datos”. En: Boletín de la Institución Tello Téllez de Meneses, 6, pp. 345-360.

Revilla Vielva, Ramón / Torres Martín, Arcadio (1954): “Arte Románico Palentino: Estudio Histórico-Crítico Descriptivo”. En: Publicaciones de la Institución Tello Téllez de Meneses, 11, pp. 45-60.

Revilla Vielva, Ramón / Torres Martín, Arcadio (1977): Camino de Santiago: pueblos enclavados en la provincia de Palencia por los que cruza la ruta. Palencia: Institución Tello Téllez de Meneses.

Rosendorf, Neal Moses (2014): Franco sells Spain to America. Hollywood, Tourism and Public relations as Postwar Spanish Soft Power. Londres-Nueva York: Palgrave Macmillan.

Sánchez Cantón, Francisco Javier (1954): “Las adquisiciones del Museo del Prado en los años 1952-1953”. En: Archivo Español de Arte, 27, 105, pp. 1-14.

Sancho Campo, Ángel (1999): "Necrológica. Arcadio Torres Martín”. En: Publicaciones de la Institución Tello Téllez de Meneses, 69, pp. 608-609.

Seymour, Charles (1961): Art Treasures for America: An Anthology of Paintings \& Sculpture in the Samuel H. Kress Collection. London: Phaidon Press, pp. 74-75, 212.

Silva Maroto, Pilar (2013): "En torno a Juan de Flandes. Pintor de corte de Isabel la Católica". En: Maestros en la sombra. Madrid: Fundación Amigos Museo del Prado, pp. 25-43.

Socias Batet, Inmaculada / Gkozgkou, Dimitra (2012): Agentes, marchantes y traficantes de objetos de arte (1850-1950). Gijón: Trea, 2012.

Socias Batet, Inmaculada / Pérez Mulet, Fernando (eds.) (2011): La dispersión de objetos de arte fuera de España en los siglos XIX y XX. Barcelona: Universidad de Barcelona, 2011.

Torres Martín, Arcadio (1951): "Retablo de Nuestra Señora de las Dueñas: Tablas pintadas por G. Calvo". En: Publicaciones de la Institución Tello Téllez de Meneses, 7, pp. 149-150.

Torres Martín, Arcadio (1953a): “Crucifijo de la Diputación”. En: Publicaciones de la Institución Tello Téllez de Meneses, 10, p. 313.

Torres Martín, Arcadio (1953b): “Mariano Timón. Escultor”. En: Publicaciones de la Institución Tello Téllez de Meneses, 10, pp. 314-316.

Torres Martín, Arcadio (1958): “Berruguete en Gante”. En: Publicaciones de la Institución Tello Téllez de Meneses, 17, pp. 144-145.

Torres Martín, Arcadio (1963): “Arenillas de San Pelayo”. En: Publicaciones de la Institución Tello Téllez de Meneses, 23, pp. 227-228.

Torres Martín, Arcadio (1971): "El Arte en Palencia a través de los tiempos”, Boletín de la Institución Tello Téllez de Meneses, 31, pp. 9-19.

Vandevivere, Ignacio / Bermejo, Elisa (1986): Juan de Flandes. Catálogo de Exposición. Madrid: Museo Nacional del Prado. 
Walker, John / Suida, William E. / Shapley, Fern Rusk (1956): Paintings and Sculpture from the Kress Colllection Acquired by the Samuel H. Kress Foundation 1951-56. Washington: National Gallery of Art.

Wunderwald Anke / Berenguer i Amat, Mireia (2001): "Les circumstàncies sobre la venda de les pintures murals de Santa María de Mur”. En: Bulletí del Museu Nacional d'Art de Catalunya, 5, pp. 121-130.

Fecha de recepción: 17-VII-2020

Fecha de aceptación: 11-XI-2020 